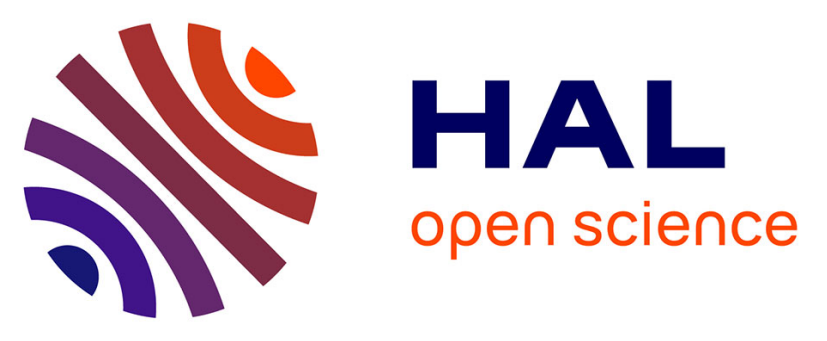

\title{
Wintertime Arctic Air Pollution over central Alaska: pre-ALPACA campaign
}

Eleftherios Ioannidis, Kathy S. Law, Jean-Christophe Raut, Tatsuo Onishi, Louis Marelle, Tjarda J Roberts, Brice Barret, Barbara d'Anna, Brice Temine-Roussel, Nicole Mölders, et al.

\section{To cite this version:}

Eleftherios Ioannidis, Kathy S. Law, Jean-Christophe Raut, Tatsuo Onishi, Louis Marelle, et al.. Wintertime Arctic Air Pollution over central Alaska: pre-ALPACA campaign. EGU General Assembly 2021, Apr 2021, Online Meeting, Germany. pp.EGU21-15477, 10.5194/egusphere-egu21-15477 . insu03194235

\section{HAL Id: insu-03194235 \\ https://hal-insu.archives-ouvertes.fr/insu-03194235}

Submitted on 6 Feb 2022

HAL is a multi-disciplinary open access archive for the deposit and dissemination of scientific research documents, whether they are published or not. The documents may come from teaching and research institutions in France or abroad, or from public or private research centers.
L'archive ouverte pluridisciplinaire HAL, est destinée au dépôt et à la diffusion de documents scientifiques de niveau recherche, publiés ou non, émanant des établissements d'enseignement et de recherche français ou étrangers, des laboratoires publics ou privés. 
EGU21-15477

https://doi.org/10.5194/egusphere-egu21-15477

EGU General Assembly 2021

(c) Author(s) 2022. This work is distributed under

the Creative Commons Attribution 4.0 License.

\section{Wintertime Arctic Air Pollution over central Alaska: pre-ALPACA campaign}

Eleftherios loannidis ${ }^{1}$, Kathy S. Law ${ }^{1}$, Jean-Christophe Raut ${ }^{1}$, Tatsuo Onishi ${ }^{1}$, Louis Marelle ${ }^{1}$, Tjarda J. Roberts ${ }^{2}$, Brice Barret ${ }^{3}$, Barbara D'Anna ${ }^{4}$, Brice Temine-Roussel ${ }^{4}$, Nicole Mölders ${ }^{5}$, Jingqiu $\mathrm{MaO}^{6}$, and William R. Simpson ${ }^{6}$

'LATMOS/IPSL, Sorbonne Université, UVSQ, CNRS, Paris, France

${ }^{2}$ LPC2E-CNRS, Université d'Orléans, Orléans, France

${ }^{3}$ LA-CNRS, Observatoire Midi-Pyrenees, Université Paul Sabatier, Toulouse, France

${ }^{4} \mathrm{LCE}, \mathrm{CNRS}$, Aix-Marseille Université, Marseille, France

${ }^{5}$ Department of Atmospheric Sciences, Geophysical Institute and College of Natural Science and Mathematics, University of Alaska Fairbanks, Fairbanks, USA

${ }^{6}$ Department of Chemistry and Biochemistry and Geophysical Institute, University of Alaska, Fairbanks, Alaska, USA

The wintertime Arctic is influenced by air pollution transported from mid-latitudes, leading to formation of Arctic Haze, as well as local emissions such as combustion for heating and power production in very cold winter conditions. This contributes to severe air pollution episodes, with enhanced aerosol concentrations, inter-dispersed with cleaner periods. However, the formation of secondary aerosol particles (sulphate, organics, nitrate) in cold/dark wintertime Arctic conditions, which could contribute to these pollution episodes, is poorly understood.

In this study, which contributes to the Air Pollution in the Arctic: Climate, Environment and Societies - Alaskan Layered Pollution and Arctic Chemical Analysis (PACES-ALPACA) initiative, the Weather Research Forecasting Model with chemistry (WRF-Chem) is used to investigate wintertime pollution over central Alaska focusing on the Fairbanks region, during the pre-ALPACA campaign in winter 2019-2020. Fairbanks is the most polluted city in the United States during wintertime, due to high local emissions and the occurrence of strong surface temperature inversions trapping pollutants near the surface.

Firstly, different WRF meteorological and surface schemes were tested over Alaska with a particular focus on improving simulations of the wintertime boundary layer structure including temperature inversions. An optimal WRF set-up, with increased vertical resolution below $2 \mathrm{~km}$, was selected based on evaluation against available data.

Secondly, a quasi-hemispheric WRF-Chem simulation, using the improved WRF setup, was used to assess large-scale synoptic conditions and to evaluate background aerosols originating from remote anthropogenic and natural sources affecting central Alaska during the campaign. The model was run with Evaluating the Climate and Air Quality Impacts of Short-Lived Pollutants (ECLIPSE) v6b anthropogenic emissions and improved sea-spray aerosol emissions. Discrepancies 
in modelled aerosols compared available data are being investigated (e.g. missing dark formation mechanisms, treatment of removal processes).

Thirdly, fine resolution simulations, using high resolution emissions (e.g. 2019 CAMS inventory), including local point sources, over the Fairbanks region, were used to investigate chemical and dynamical processes influencing aerosols under different meteorological conditions observed during the field campaign including a cold stable episode and a period with possible mixing of air masses from aloft. The model was evaluated against available aerosol, oxidant (ozone) and aerosol precursor data from surface monitoring sites and collected during the pre-campaign, including vertical profile data collected in the lowest $20 \mathrm{~m}$. The sensitivity of modelled aerosols to meteorological factors, such as relative humidity, temperature gradients and vertical mixing under winter conditions are investigated. 